\title{
De zeeman en de seculaire trend. De Nederlandse vrachtvaart als bron van werkgelegenheid omstreeks 1700
}

\section{P. C. VAN ROYEN}

Eeuwenlang is de vrachtvaart in Europese wateren één van de belangrijkste sectoren van het economisch leven van Nederland geweest. Vooral in de zeventiende en achttiende eeuw bood deze tak van scheepvaart aan vele handen werk en was ze een bron van bedrijvigheid voor tal van andere economische sectoren. Gezien het grote belang van de koopvaardij is het niet onaannemelijk dat deze kan dienen als een graadmeter van bepaalde ontwikkelingen binnen het economisch leven van de Republiek in het algemeen. Meer en gedetailleerder kennis van de vrachtvaart kan aldus bijdragen tot een beter inzicht in het reilen en zeilen van de Nederlandse economie in de zeventiende en achttiende eeuw. Tot de tweede helft van de zeventiende eeuw werd deze economie gekenmerkt door expansie. Over de ontwikkelingen daarna lopen de opvattingen van historici uiteen. Sommigen menen dat de economie van de Republiek in absolute zin achteruitging, anderen houden het op een relatieve achteruitgang of stagnatie, en weer anderen zijn van mening dat ook in de achttiende eeuw er nog steeds sprake was van een - zij het tragere dan voorheen — economische groei ${ }^{1}$. Bij de huidige stand van wetenschap is een ondubbelzinnige oplossing van dit probleem eigenlijk nog niet goed mogelijk. Het feit alleen al dat op grond van hetzelfde materiaal volstrekt tegengestelde conclusies worden getrokken, maakt dat duidelijk.

Wie iets wilde weten over de ontwikkeling van de vrachtvaart van de Republiek vanaf de zestiende tot en met de achttiende eeuw, ging al snel te rade bij Het Noorderkwartier van A. M. van der Woude ${ }^{2}$. Daarin worden onder meer met brede streken de opbloei en teloorgang van de vrachtvaart van Noord-Holland benoorden het IJ geschetst. Het materiaal waarop de schets van deze ontwikkeling is gebaseerd, is echter noodgedwongen mager. 'Wat wij konden vinden waren dan ook toevallige bijproducten van gegevens, die voor andere doeleinden aangelegd werden' ${ }^{\prime 3}$. De paragraaf over de scheepvaart sluit Van der Woude aldus af:

Kortom, het onderzoek naar dit stuk van de zeegeschiedenis moet nog beginnen. Het zal velerlei gegevens naar voren moeten brengen: over de omvang van de handelsvloot, de gemiddelde scheepsgrootte, de daarmee corresponderende omvang van de bemanning, over de samenstel-

1 J. C. Riley, 'The Dutch Economy after 1650: Decline or Growth?', Journal of European Economic History, XIII (1984) 521-569; J. L. van Zanden, 'De economie van Holland 1650-1805', Bijdragen en mededelingen betreffende de geschiedenis der Nederlanden, CII (1987) 562-609.

2 A. M. van der Woude, Het Noorderkwartier. Een regionaal historisch onderzoek in de demografische en economische geschiedenis van westelijk Nederland van de late middeleeuwen tot het begin van de negentiende eeuw (Wageningen, 1972).

3 Van der Woude, Noorderkwartier, 363. 
ling van de bemanning in de verschillende perioden, over de internationale concurrentiepositie van onze vrachtvaart in verband met de arbeidskosten ... ${ }^{4}$.

In zijn recente artikel 'De contractiefase van de seculaire trend in het Noorderkwartier nader beschouwd' komt Van der Woude voor de dag met nieuw materiaal, waardoor hij zijn ideeën betreffende de economische en demografische ontwikkelingen in met name het Noorderkwartier nog eens ziet bevestigd ${ }^{5}$. In een niet onaanzienlijk aantal pagina's van zijn artikel weidt Van der Woude uit over de vrachtvaart als bron van werkgelegenheid in het Noorderkwartier na ongeveer 1650. Daarbij maakt hij onder andere gebruik van een gedeelte van de onderzoeksresultaten uit mijn proefschrift Zeevarenden op de koopvaardijvloot omstreeks $1700^{6}$.

In Zeevarenden heb ik geprobeerd met behulp van een nieuwe bron, de zogenaamde scheepsverklaringen in combinatie met bevrachtingscontracten uit de notariële archieven van onder andere Amsterdam, een aantal van de door Van der Woude gestelde vragen op te lossen. Het onderzoek heb ik geconcentreerd op de periode 1700 tot en met 1710. En daarvoor was een goede reden. Volgens Van der Woude zouden namelijk diverse gegevens erop wijzen dat tussen 1630 en 1710 de schippers uit Noord-Holland benoorden het IJ, en dat tussen 1650 en 1740 de zeelui uit deze regio verdwenen ${ }^{7}$. Een goede verklaring voor het verdwijnen van deze zeelui was echter moeilijk te vinden:

Ten eerste kan er in Noord-Holland los van de vraag naar arbeidskrachten een autonome demografische ontwikkeling hebben plaatsgegrepen, die het reservoir van potentiële zeelieden heeft doen opdrogen... Als tweede mogelijkheid kan men veronderstellen, dat de Noordhollandse zeelieden onder aanhoudende concurrentie langzaam maar zeker van de arbeidsmarkt verdreven zijn ${ }^{8}$. Toch is deze ontwikkeling bij de huidige stand van onze kennis een mysterieuze zaak $^{9}$.

De veruit belangrijkste bron die ten grondslag ligt aan deze bevinding van Van der Woude, wordt gevormd door cijfermateriaal uit de zogenaamde Sonttoltabellen ${ }^{10}$. Op basis van de krimpende aantallen doorvaarten van Noordhollandse schippers door de Sont nam Van der Woude aan dat dus het aantal schippers uit Noord-Holland afnam. Ervan uitgaand dat een schipper het merendeel van zijn bemanning uit de naaste omgeving betrok, gebruikte Van der Woude het aantal doorvaarten van Noordhollandse schippers door de Sont als een 'barometer' voor het belang van de vrachtvaart als bron

4 Ibidem, 398.

5 A. M. van der Woude, 'De contractiefase van de seculaire trend in het Noorderkwartier nader beschouwd', Bijdragen en mededelingen betreffende de geschiedenis der Nederlanden, CHI (1988) 373398, speciaal 387-398.

6 P. C. van Royen, Zeevarenden op de koopvaardijvloot omstreeks 1700 (Amsterdam, 1987).

7 Van der Woude, Noorderkwartier, 395.

8 Ibidem, 396-397.

9 Ibidem, 395.

10 N. E. Bang, K. Korst, Tabeller over skibsfart og varetransport gennem Oresund (KopenhagenLeipzig, 1906-1953) I-VI. 
van werkgelegenheid in dit gebied. Verdwijnen de schippers, dan verdwijnen de zeelui.

Tot op heden is deze mening door diverse historici overgenomen. J. Lucassen laat in zijn beschrijving van de arbeidscyclus op het Noordhollandse platteland de zeevaart als onderdeel van deze cyclus na 1680 geheel vervallen ${ }^{11}$. A. Knotter gebruikt de tot nog toe onomstreden gegevens uit de ondertrouwregisters van Amsterdam om aan te tonen dat het met het Noordhollandse aanbod van zeelui na 1650 bergafwaarts ging ${ }^{12}$. In een coproduktie met J. L. van Zanden wordt op basis van deze zelfde ondertrouwregisters zelfs beweerd dat al in het tweede kwart van de zeventiende eeuw de Hollandse èn Friese kuststreken als recruteringsgebied voor zeelui tekort schoten ${ }^{13}$.

Bij deze hier en daar wellicht wel erg vergaande beweringen zou men zich de vraag kunnen stellen, wat nu feitelijk bekend is over de zeevarenden in Holland (en Friesland). Is de veronderstelling van Van der Woude niet te veel een eigen leven gaan leiden? Alle auteurs verwijzen naar de hierboven aangehaalde uitspraken en scherpen deze vervolgens aan, al dan niet geruggesteund door nieuw cijfermateriaal. En de oorspronkelijke veronderstelling was voornamelijk gebaseerd op de aantallen schippers, zoals te vinden in de Sonttoltabellen. Maar kunnen deze tabellen inderdaad gebruikt worden als een barometer van het aantal zeevarenden in een bepaald gebied? Dat wil zeggen, is er een correlatie tussen de plaats van herkomst van de schipper en die van zijn scheepsvolk? Is er een noodzakelijke samenhang tussen de demografische achteruitgang in Noord-Holland benoorden het IJ en een afnemend belang van de vrachtvaart? Om een antwoord op deze vragen te krijgen zullen we eerst moeten vaststellen of de gegevens uit deze Sonttoltabellen een correct beeld geven van de gebieden van herkomst van de Nederlandse schippers. J. Th. Lindblad en P. de Buck hebben door middel van een vergelijkend onderzoek tussen de galjootsgeldregisters en de Sonttoltabellen aangetoond dat men in elk geval wat betreft de achttiende eeuw niet moet blind varen op de Sonttoltabellen, als het om de plaats van herkomst van de schippers gaat ${ }^{14}$. Onderzoek van P. Boon heeft dat nog duidelijker gemaakt voor de periode $1681-1720^{15}$. Maar hoe men het ook wendt of keert, een sensationele aardverschuiving in regionaal opzicht treedt door deze onderzoeken niet op. Wel geven hun resultaten aan dat - na correctie van de oorspronkelijke gegevens over de herkomstplaatsen van de schippers volgens de Sonttoltabellen en Sonttolregisters — de achteruitgang in bepaalde regio's of plaatsen minder abrupt was dan tot op heden werd aan-

11 J. Lucassen, Naar de kusten van de Noordzee (Gouda, 1984) 164.

12 A. Knotter, 'De Amsterdamse scheepvaart en het Noordhollandse platteland in de 16de en 17de eeuw. Het probleem van de arbeidsmarkt', Holland, XVI (1984) vi, 281-290, speciaal 287-289.

13 A. Knotter, J. L. van Zanden, 'Immigratie en arbeidsmarkt te Amsterdam in de 17e eeuw', Tijdschrift voor sociale geschiedenis, XIII (1987) iv, 421.

14 J. Th. Lindblad, P. de Buck, 'Shipmasters in the Shipping between Amsterdam and the Baltic, 17221780', in: Interactions of Amsterdam and Antwerp with the Baltic Region, 1400-1800 (NEHA Werken LVI; Leiden, 1983) 133-152.

15 P. Boon, 'West Friesland and the Sound (1681-1720). Sound Toll Registers, Sound Toll Tables and the Facts in West Friesland', in: W. G. Heeres, e. a., ed., From Dunkirk to Danzig. Shipping and Trade in the North Sea and the Baltic, 1350-1850 (Hilversum, 1988) 171-189. 
genomen. Daarbij blijft het de vraag of het juist is te veronderstellen dat als Noordhollandse schippers zich niet meer in de Sont vertoonden, de totale Noordhollandse scheepvaart was verdwenen. Het verdwijnen van deze schippers in de Sonttoltabellen kan namelijk ook op een andere manier worden verklaard.

Zoals bekend, onderging de Nederlandse scheepvaart in de jaren rond 1600 een indrukwekkende expansie. Alle Europese wateren werden halverwege de zeventiende eeuw door, inwoners van de Republiek bevaren. Daarnaast werd in 1602 de VOC opgericht, die in toenemende mate een beroep zou doen op de arbeidsmarkt. De WIC begon haar activiteiten na 1621, terwijl de walvisvaart pas na de opheffing van de Noordse Compagnie (1642) een hoge vlucht zou nemen. Het merendeel van deze maritieme bezigheden werd ondernomen vanuit de kustprovincies Holland en Zeeland. Het is derhalve heel goed mogelijk dat schippers uit Noord-Holland vanaf het begin van de zeventiende eeuw in toenemende mate iets anders hadden te doen dan uitsluitend naar de Oostzee varen. Een aanwijzing voor de juistheid van deze veronderstelling vinden we in De oudste Lastgeldrekeningen van Directeuren van de Levantse Handel, lopend over de periode 1625 tot en met $1631^{16}$. Van de 223 ontvangsten waren 31 afkomstig van Amsterdamse schippers, 80 van schippers uit het Noorderkwartier, 77 van Westfriese schippers, 4 van schippers uit Friesland, 3 van schippers van de Waddeneilanden, 10 van schippers uit Zuid-Holland, 5 van Zeeuwse schippers, 2 van buitenlandse en 10 van niet nader aangeduide schippers. Dus in dit geval kwam $70 \%$ van de vaart op het Middellandse-Zeegebied voor rekening van Noordhollandse schippers. In het register van persoonsnamen van de bronnenpublikatie van K. Heeringa over de vaart op het Middellandse-Zeegebied ( 1590-1660) staan de namen van 336 schippers, van wie er alleen al 197 uit Noord-Holland kwamen ${ }^{17}$. Friezen en Waddeneilanders telden in deze tak van vrachtvaart vrijwel niet mee. Het kan geen puur toeval zijn dat we deze laatsten in de loop van de zeventiende eeuw in toenemende aantallen in de Sont zien verschijnen, terwijl de Noordhollandse schippers het daar lieten afweten.

In de eerste helft van de zeventiende eeuw kreeg ook de houtvaart op Noorwegen een krachtige impuls. In deze tak van vrachtvaart was tussen 1630 en 1640 sprake van een hausse ${ }^{18}$. En ook hier namen Noordhollandse schippers, zij het in mindere mate dan in de vaart op het Middellandse-Zeegebied, een groot aantal vaarten voor hun rekening. De vaart op Portugal behoorde eveneens tot het vaargebied van de Noordhollanders. Tegen het einde van de zeventiende eeuw hadden Hoornse schippers haast een soort van monopolie van de vaart op Setubal ${ }^{19}$. Een andere aanwijzing dat de 'moedernegotie' van veel minder groot belang was voor de schippers van Noord-Holland vin-

16 W. F. H. Oldewelt, De oudste Lastgeldrekeningen van Directeuren van de Levantse Handel (16251631) (Amsterdam, 1958).

17 K. Heeringa, Bronnen tot de geschiedenis van den Levantschen handel 1590-1660 ('s-Gravenhage, 1910) I, 1139-1170: Holland 4; Amsterdam 52; Noord-Holland 197; Zuid-Holland 47; Friesland 6; Waddeneilanden 4; Zeeland 24; rest 2; totaal 336.

18 J. Schreiner, Nederland og Norge 1625-1650. Trelastutforsel og handelspolitikk (Oslo, 1933) 109.

19 Boon, 'West Friesland and the Sound', 188. 
den we in de zogenaamde paalgeldregisters. Van de 168 schepen die in 1681 paalgeld moesten betalen in Hoorn, kwamen er maar vier uit de Baltische regio. In Enkhuizen was dat aantal in 1683 slechts 26 van de 136. In Medemblik was het in 1685 één van de $39^{20}$.

Daarnaast bestaan er aanwijzingen dat de moedernegotie in de loop van de zeventiende, maar vooral aan het begin van de achttiende eeuw tijdelijk in belang verminderde. J. A. Faber heeft de aandacht gevestigd op de afnemende graanaanvoer vanuit de Baltische landen en vond daar een viertal mogelijke verklaringen voor ${ }^{21}$. In een later artikel wijst Faber nog een verklaring aan die zijns inziens het meeste gewicht in de schaal legt: de toenemende export van graan vanuit Engeland naar de Republiek ${ }^{22}$. In een tweetal buitengewoon boeiende publikaties levert D. Ormrod het bewijsmateriaal voor deze veronderstelling ${ }^{23}$.

Most significant... was the fact that Holland remained the initial destination for the bulk of English re-export in the earlier decades of the [ 18th] century - from whence they were reexported a second time by the Dutch, in some cases after processing ${ }^{24}$.

Juist vanaf het begin van de achttiende eeuw begon de export van Engels broodgraan naar de Republiek in toenemende mate de export van Baltisch graan te substitueren ${ }^{25}$. Door deze 'nieuwe' ontwikkeling boette de moedernegotie tijdelijk in aan belang zonder dat dit overigens leidde tot een inkrimping van de vrachtvloot. Een groot deel van dit graan werd namelijk met Nederlandse schepen weer naar elders vervoerd.

Dit alles wil zeggen dat in de eerste plaats de Noordhollandse schippers vanaf het eerste kwart van de zeventiende eeuw in alle takken van vrachtvaart sterk tot zeer sterk waren vertegenwoordigd. Hun afnemend aantal in de vaart op het Oostzeegebied kan dus ook verklaard worden uit de omstandigheid dat zij niet overal tegelijkertijd konden zijn. In de tweede plaats maakt het onderzoek van Ormrod duidelijk dat fluctuaties in de vaart naar en vanuit de Oostzee niet per se een uitdrukking hoeven te zijn van een afnemend belang van de Nederlandse vrachtvaart, maar van een afnemend belang van de Oostzee als vaargebied. De Sonttoltabellen alleen vormen dus niet een voldoende betrouwbaar criterium voor het bepalen van het belang van de Noordhollandse of Nederlandse scheepvaart. Mijn onderzoek in de scheepsverklaringen en bevrachtingscontracten maakt dat ook voldoende duidelijk: in de periode 1700-1710 kwam 28\%

20 Ibidem, 187.

21 J. A. Faber, 'Het probleem van de dalende graanaanvoer uit de Oostzeelanden in de tweede helft van de zeventiende eeuw', AAG-Bijdragen, IX (Wageningen, 1963) 3-24.

22 J. A. Faber, 'De Sontvaart als spiegel van de structuurveranderingen in de Europese economie gedurende de achttiende eeuw', Tijdschrift voor Zeegeschiedenis, I (1982) ii, 91-101.

23 D. Ormrod, 'English Grain Exports and the Structure of Agrarian Capitalism, 1700-1760', Occasional Papers in Economic and Social History, XII (Hull, 1985); Idem, 'English Re-exports and the Dutch Staplemarket in the Eighteenth Century', in: D. C. Coleman, P. Mathias, ed., Enterprise and History. Essays in Honour of Charles Wilson (Cambridge, 1984) 89-115.

24 Ormrod, 'English Re-export', 96.

25 Idem, 'English Grain Exports', 47. 
van de opgespoorde schippers uit Noord-Holland benoorden het $\mathrm{IJ}^{26}$. Ook al wezen de Sonttoltabellen op een verdwijnen van de Noordhollandse schippers, de gegevens uit de notariële archieven laten zien dat zij nog volop aanwezig zijn. Dat hoeft natuurlijk niet te betekenen dat de vrachtvaart als bron van werkgelegenheid in Noord-Holland benoorden het IJ dus ook niet verdwenen was. De Noordhollandse schippers konden immers gebruik maken van bemanningen die van elders kwamen. Dit brengt ons bij de tweede vraag. Was er een samenhang tussen de plaats van herkomst van schipper en die van zijn scheepsvolk?

Van der Woude veronderstelde dat een dergelijke correlatie zeer aannemelijk was ${ }^{27}$. Uit mijn onderzoek in de scheepsverklaringen blijkt hoe juist deze veronderstelling is. Ook in de jaren 1700-1710 haalden de Noordhollandse schippers een groot deel van hun bemanning uit hun naaste omgeving ${ }^{28}$. Maar nu komt het probleem. De Noordhollandse vrachtvaart zou, aldus Van der Woude, na 1700 vrijwel zijn verdwenen. Noordhollandse zeelui zouden er na 1700 haast niet meer te vinden zijn. In ieder geval tussen 1700 en 1710 echter was het proces van verdwijnen van zeelui en schippers uit deze regio aanmerkelijk minder ver gevorderd dan op grond van de uitspraken van Van der Woude mocht worden aangenomen. Het aanvankelijk zo logisch ogende verband tussen het afnemende aantal Noordhollandse schippers in de Sonttoltabellen, de demografische achteruitgang in Noord-Holland benoorden het IJ en het toenemend aantal klachten over gebrek aan scheepsvolk uit deze contreien wordt nu wel zwaar op de proef gesteld. Men kan zich zelfs de vraag stellen of dit verband wel zo noodzakelijk is $^{29}$.

In Drie eeuwen Friesland schetst Faber aan de hand van gelijksoortig materiaal als Van der Woude heeft gebruikt de demografische, sociale en economische ontwikkeling van Friesland ${ }^{30}$. Evenals in Noord-Holland trad in dit gewest in de tweede helft van de zeventiende eeuw en de eerste helft van de achttiende eeuw een periode van stagnatie en achteruitgang in de bevolkingsaantallen op ${ }^{31}$. De achteruitgang was vooral duidelijk merkbaar in het maritiem georiënteerde westen en in de steden van Friesland. Bezien we echter het aantal doorvaarten van Friese schippers door de Sont in deze periode, dan neemt dit juist toe. Dank zij het al eerder genoemde onderzoek van Lindblad en De Buck weten we dat die toename in feite zelfs nog sterker moet zijn ge-

26 Van Royen, Zeevarenden, 82.

27 Van der Woude, Noorderkwartier, 374; 'Hoewel dit niet direct aanwijsbaar is en theoretisch denkbaar, dat de schippers uit geheel andere plaatsen kwamen dan het overig scheepsvolk, ligt het wel voor de hand een zekere geografische correlatie tussen de vermeldingen van de woonplaatsen van de schippers en het overig zeevolk te veronderstellen'.

28 Van Royen, Zeevarenden, hoofdstuk 3.

29 Van der Woude, Noorderkwartier, 395: '... alles wijst erop dat het met de scheepvaart in het Noorderkwartier na 1700 vrij spoedig gedaan was en dat dit proces van verdwijnen zich ook reeds in de tweede helft van de $17 \mathrm{e}$ eeuw aan het voltrekken was. De gelijktijdigheid met de demografische achteruitgang ... is te opvallend om aan een toeval te denken'.

30 J. A. Faber, Drie eeuwen Friesland. Economische en sociale ontwikkelingen van 1500 tot 1800 (Wageningen, 1972).

31 Faber, Drie eeuwen Friesland, 413-415. 
weest. De samenhang derhalve tussen de demografische achteruitgang en het afnemend aantal schippersvermeldingen in de Sonttoltabellen ligt dus helemaal niet zo voor de hand als wordt aangenomen.

Op grond van de gegevens uit de scheepsverklaringen en die uit de bevrachtingscontracten ben ik in Zeevarenden dan ook tot de conclusie gekomen dat de vrachtvaart in Noord-Holland benoorden het IJ in elk geval tussen 1700 en 1710 nog steeds een belangrijke bron van werkgelegenheid was, ook voor Noordhollandse zeelieden. Vooral dit laatste heeft Van der Woude in zijn artikel 'De contractiefase' willen weerleggen. De schippers uit Noord-Holland waren dan wel niet verdwenen, het varend volk was dat wel. Zij hadden plaats moeten maken voor (goedkopere) Friese en buitenlandse arbeidskrachten. Om dat te bewijzen heeft hij gebruik gemaakt van mijn cijfermateriaal, echter in een herziene versie ${ }^{32}$.

Bij het eerste gedeelte van zijn berekening komt Van der Woude dicht in de buurt van mijn eindresultaten, al ben ik het niet helemaal eens met zijn berekeningswijze ${ }^{33}$. Pertinent onjuist is de wijze waarop Van der Woude in zijn artikel al mijn gegevens betreffende de geografische herkomst van het scheepsvolk per regio op een grote hoop gooit om vervolgens erop te wijzen dat het aandeel van de buitenlanders onder de zeevarenden veel hoger moet zijn geweest dan ik heb gesuggereerd. In de eerste plaats is

Nederlanders en buitenlanders in hoge en lage rangen, verdeeld naar gebied van herkomst van de schipper.

$\begin{array}{lrrrrrrrrrr} & \text { totaal } & \text { reis } & \text { hr } & \text { nhr } & \text { bhr } & \text { Ir } & \text { nlr } & \text { blr } & \text { bip } \\ \text { Nkw } & 4551 & 367 & 1468 & 1299 & 169 & 2716 & 1901 & 815 & 22 & \% \\ \text { WFr } & 5747 & 449 & 1796 & 1626 & 170 & 3502 & 2381 & 1121 & 22 & \frac{\circ}{0} \\ \text { Frl } & 6490 & 488 & 1952 & 1845 & 107 & 4050 & 2713 & 1337 & 22 & \% \\ \text { Wad } & 8723 & 715 & 2860 & 2553 & 307 & 5148 & 3449 & 1699 & 23 & \% \\ & & & & & & & & & & \\ \text { Tot } 25511 & 2019 & 8076 & 7323 & 753 & 15416 & 10444 & 4972 & 22,4 & \% \\ \text { Ams } & 10286 & 556 & 2224 & 1379 & 845 & 7506 & 3528 & 3978 & 47 & \%\end{array}$

Toelichting: reis = aantal reizen (= aantal schippers); $\mathrm{hr}=$ totaal aantal arbeidsplaatsen in hoge rangen, met uitzondering van de schippers; $\mathrm{nhr}=$ Nederlandse aandeel in de hoge rangen; $\mathrm{bhr}=$ buitenlandse aandeel in de hoge rangen; $\mathrm{Ir}=$ totaal aantal arbeidsplaatsen in de lage rangen; $\mathrm{nlr}=$ Nederlandse aandeel in de lage rangen; blr = buitenlandse aandeel in de lage rangen; bip = percentage buitenlanders onder de totale bemanning; $\mathrm{Nkw}=$ Noorderkwartier; $\mathrm{WFr}=$ West-Friesland $; \mathrm{Frl}=$ Friesland $; \mathrm{Wad}=$ Waddeneilanden , Ams = Amsterdam. Het verschil met de berekeningswijze van Van der Woude schuilt hierin, dat Van der Woude niet de geografische herkomst per rang heeft berekend, maar eenvoudigweg het aantal attestanten van de totale geschatte bemanning heeft afgetrokken om vervolgens de rest te delen door het percentage buitenlandse bootsgezellen. We kunnen er gevoeglijk van uitgaan dat elk schip een schipper, stuurman, hoogbootsman, timmerman en kok telde. Voor de 'hoge' rangen kan aldus op verfijnde wijze de geografische samenstelling worden berekend. Wie we overhouden, kunnen gerekend worden tot de bootsgezellen (de 'lage' rang). Met behulp van het herkomstpercentage van de buitenlanders onder deze categorie varensgasten kunnen we de omvang van het buitenlandse element onder hen vaststellen. De cijfers van deze tabel zijn gebaseerd op de tabellen 3-5 t/m 3-8, 3-10 t/m 3-13 en 5-8 uit Zeevarenden. 
het niet verstandig om de beperkte gegevens betreffende Zuid-Holland, Zeeland en Groningen in de berekeningen te betrekken. Ik onthoud mij ten aanzien van deze regio's van uitspraken. In de tweede plaats maak ik een onderscheid tussen Amsterdam en de noordelijke gebieden, Noorderkwartier, West-Friesland, Friesland en de Waddeneilanden. Zoals men in de hoofdstukken 3 en 4 van Zeevarenden kan lezen, verschilde het recruteringspatroon van de Amsterdamse schippers fundamenteel van dat van hun collega's uit de andere gebieden. In de derde plaats, van speciaal belang is de samenstelling van het scheepsvolk op schepen van schippers uit Noord-Holland. Immers, daar zou de vrachtvaart als bron van werkgelegenheid na 1700 vrijwel zijn verdwenen.

Uit mijn onderzoek blijkt dat het percentage buitenlanders in dienst van schippers uit Noord-Holland, Friesland en van de Waddeneilanden bij de $25 \%$ blijft steken. Amsterdamse schippers echter maakten in sterke mate gebruik - en dat ligt voor de hand van de Amsterdamse, dus kosmopolitische, arbeidsmarkt. De schippers uit NoordHolland recruteerden hun scheepsvolk van de regionale arbeidsmarkt. Er waren dus nog steeds zeelieden in het Noorderkwartier en West-Friesland. En of onder invloed van het hoge percentage buitenlanders onder commando van Amsterdamse schippers het totale percentage buitenlanders op de Nederlandse koopvaardijvloot daardoor toeneemt, doet daar niets aan af.

Bij zijn tweede stap om mijn gegevens 'in te passen' in zijn bewijsmateriaal maakt Van der Woude gebruik van een verdeelsleutel met behulp waarvan het percentage buitenlanders met $15 \%$ wordt verhoogd ${ }^{34}$. Omdat Nederlandse zeelieden vaker voor een notaris verschenen dan buitenlandse zeelui, moet de eerste groep, aldus Van der Woude, worden 'ingedikt' en de tweede 'opgerekt'. Maar hoe zwaar weegt een ingedikte zeeman? En waarom worden de schippers twee keer meegerekend ${ }^{35}$ ? Door het vergelijken van deze twee groepen (de Nederlanders die vaak voorkomen, en de bui-

\footnotetext{
34 Van der Woude, 'Contractiefase', 392-393.

35 Wellicht is het hier de beste plaats een aantal misverstanden over vermeende reken- en telfouten uit de weg te ruimen. De merkwaardige verschillen die Van der Woude ('Contractiefase', 392, noot 31) constateert tussen de diverse tabellen in Zeevarenden, laten zich eenvoudig verklaren. Allereerst, de onjuiste optelling in tabel 3-1 (Zeevarenden, 82). Ik dacht niet dat het de gewoonte was een drukfout, hoe ernstig deze in dit geval ook is, te critiseren. Zie voor het juiste cijfer bij voorbeeld pagina 90 . Ten tweede: de vijf schippers wier exacte woonplaats in de Republiek niet bekend was, zijn niet in de tellingen van hoofdstuk 3 betrokken (Zeevarenden, 90). Alleen bij de behandeling van de schrijfvaardigheid en leeftijdsopbouw van de zeelui zijn hun varensgasten meegeteld onder het motto: hoe meer gegevens, hoe beter. Zoals uit de bijlagen 8 en 9 blijkt, leverde Schiermonnikoog in de jaren $1700 \mathrm{t} / \mathrm{m} 1710$ geen schippers. $\mathrm{Er}$ is derhalve geen enkele reden deze schippers bij Groningen te rekenen ('Contractiefase', 390). Ten derde: de verschillen in de tabellen betreffende de schrijfvaardigheid en leeftijdsopbouw in hoofdstuk 4 leveren uiteraard niet dezelfde totalen op als die in tabel 4-1. In een oogopslag kan men zien dat in de eerste kolom van de tabellen 4-3 en 4-6 t/m 4-13 de schippers ontbreken. Dat spreekt vanzelf, want de scheepsverklaring werd op hun verzoek afgelegd. Hun leeftijd werd niet genoteerd, evenmin zetten zij hun handtekening onder de verklaring. Eenvoudigweg het aantal schippers bij deze totalen optellen geeft evenmin de gewenste som. Namelijk, sommige schippers begonnen hun carrière in een lagere rang. Zij zijn in hun op één na hoogste positie wel meegerekend. Omdat buitenlandse schippers niet in het onderzoek zijn betrokken, treedt een dergelijk verschil uiteraard niet op in de tabellen met betrekking tot de buitenlanders. Ik geef graag toe dat dit alles wellicht uitgebreider had moeten worden toegelicht.
} 
tenlanders die sporadisch voorkomen) veronderstelt Van der Woude dat het om een vaste, statische groep buitenlanders ging. Maar hun al dan niet frequent voorkomen, zegt feitelijk niets over het totaal aandeel dat door buitenlanders werd ingenomen op de vrachtvaart. Niet elk jaar hoefde dezelfde buitenlandse zeeman naar de Lage Landen te komen om zijn arbeidskracht aan te bieden. De hoge frequentie van de Nederlanders onder de bemanningen geeft aan dat zij vrijwel elk jaar weer ter vrachtvaart voeren. De lage frequentie van de buitenlandse zeelui maakt duidelijk dat zij meer een vlottend deel van de arbeidsmarkt waren.

Is de wijze waarop Van der Woude mijn cijfermateriaal hanteert al laakbaar, de beargumentering van de juistheid van zijn eigen interpretatie laat eveneens te wensen over. Ter verklaring van het in toenemende mate gebruik maken van Friese en/of buitenlandse arbeidskrachten door Noordhollandse schippers voert Van der Woude de relatief lage lonen van deze zeelui aan $^{36}$. Maar, voor zover bekend, waren er geen verschillen in loon tussen Noordhollandse, Friese of buitenlandse varensgasten ${ }^{37}$. Uit lopend onderzoek in monsterrollen opgemaakt door de Amsterdamse waterschout aan het begin van de negentiende eeuw blijkt evenmin sprake van een dergelijk verschil ${ }^{38}$. Derhalve is dit argument vooralsnog een slag in de lucht en kunnen we voorlopig constateren dat Van der Woude niet met plausibel materiaal aankomt, waarmee mijn cijfermateriaal wordt weerlegd.

$\mathrm{Nu}$ is het bij het doen van een nieuwe vondst altijd zaak goed in de gaten te houden of de wens niet te zeer de vader van de gedachte wordt. Een vlaag van 'archief-blindheid' mag niet bij voorbaat worden uitgesloten. Laten we daarom eens bekijken hoe en met welk materiaal een aantal van de hiervoor genoemde auteurs tot een bevestiging is gekomen van de hypothese dat de vrachtvaart als bron van werkgelegenheid in Noord-Holland benoorden het IJ na 1700 vrijwel was verdwenen.

Knotter heeft in een eerste poging ter verklaring van de mysterieuze verdwijning van de Noordhollandse zeelui gebruik gemaakt van de door S. Hart verzamelde gegevens uit de ondertrouwregisters van Amsterdam (tabel 1) ${ }^{39}$. In samenwerking met Van Zanden is dit materiaal op nog uitgebreider schaal gebruikt. In beide artikelen zijn de auteurs er a priori van uitgegaan dat de hypothese van Van der Woude correct was.

36 Van der Woude, 'Contractiefase', 395-396.

37 G. J. A. Raven, "Aanhoudend sukkelen om bootsvolk'. Een keerpunt in het personeelsbeleid van de marine, 1775-1795', Tijdschrift voor Zeegeschiedenis, I, (1982) ii, 132-142; J. Lucassen ('Zeevarenden', in: Maritieme Geschiedenis der Nederlanden, II (Bussum, 1977) 144) en J. R. Bruijn ('Zeevarenden', in: Maritieme Geschiedenis der Nederlanden, III, 171) maken bij de bespreking van lonen in de diverse takken van scheepvaart geen melding van dergelijke verschillen.

38 Dit voorlopige resultaat dank ik aan de studenten sociale en economische geschiedenis aan de VU, die in het cursusjaar 1987-1988 deelnamen aan het werkcollege 'Een nieuw begin. De Nederlandse scheepvaart tijdens de eerste helft van de negentiende eeuw'. Onderzoek is onder andere gedaan in de monsterrollen van de Amsterdamse waterschout uit de jaren 1814-1816 en 1825-1826 (GAA, inv. nr. 38). Definitieve onderzoeksresultaten zullen te zijner tijd worden gepubliceerd.

39 Knotter,'Amsterdamse scheepvaart', 281-290. 
Tabel 1 Aantal Noordhollanders onder de te Amsterdam ondertrouwde zeelieden, 1586-1700

\begin{tabular}{crrr} 
& \multicolumn{2}{c}{ Noordhollanders } & Totaal \\
$1586-1600$ & 166 & $(12,4 \%)$ & 1334 \\
$1601-1625$ & 412 & $(11,9 \%)$ & 3468 \\
$1626-1650$ & 631 & $(6,7 \%)$ & 9392 \\
$1651-1675$ & 453 & $(4,6 \%)$ & 9791 \\
$1676-1700$ & 322 & $(3,8 \%)$ & 8430
\end{tabular}

Bron: Knotter, 'Amsterdamse scheepvaart', 287.

Op basis van de cijfers uit tabel 1 is Knotter van mening dat het aanbod van varensgasten uit Noord-Holland eigenlijk al vóór 1650 sterk terugliep ${ }^{40}$. Bezien we deze reeks echter nauwkeuriger, dan blijkt dat we te maken hebben met een jaarlijks gemiddelde (per periode van vijfentwintig jaar) van respectievelijk 11, 16, 25, 18 en 13 Noordhollandse zeelieden, die in Amsterdam een eerste huwelijk wilden aangaan. Bedenken we dat de jaarlijkse vraag naar zeelui in 161033.000 , in 164046.000 en in 168050.000 man was, dan lijkt deze 'steekproef' aan de kleine kant ${ }^{41}$. Afgezet tegen het jaarlijks aanbod in de eerste helft van de zeventiende eeuw van zeelieden uit NoordHolland benoorden het IJ van tussen de 13.500 en 17.500, blijven deze aantallen ook onder de maat ${ }^{42}$.

Er is met dit materiaal echter meer aan de hand. Als de Amsterdamse scheepvaart inderdaad zo'n zuigkracht had op het Noordhollandse potentieel van zeevarenden, dan zouden we deze op z'n minst weerspiegeld moeten zien in een groter aantal Noordhollandse bruidegoms dan bruiden. De zeevaart is immers een exclusieve herenzaak. De sexratio (het aantal vrouwen op honderd mannen) schommelt echter rond de honderd $^{43}$. Dat geeft aan dat de stroom van migranten van het Noordhollands platteland naar sexe evenwichtig was opgebouwd. Van aantrekkingskracht op een uitsluitend mannelijke groep arbeidskrachten is geen sprake. Hart zelfwees er overigens al op dat

40 Uit deze tabel blijkt, aldus Knotter ('Amsterdamse scheepvaart', 287), dat 'het aandeel van Noordhollanders onder de in Amsterdam ondertrouwde zeelieden na 1625 aanzienlijk is gedaald, hoewel hun aantal in absolute zin nog toenam. Met bovengenoemde restrictie [namelijk dat een niet nader te kwantificeren deel van deze zeelui in zijn eigen woonplaats elders bleef wonen] zou dit betekenen, dat het Noordhollandse aanbod van zeelieden na circa 1625 sterk achterbleef bij de toename van de Amsterdamse vraag. In de periode 1651/1675 daalt ook het absolute aantal Noordhollanders, terwijl het totale aantal zeelui nog groeit. De daling van het aantal Noordhollanders kan dus niet aan een vermindering van de vraag naar scheepsvolk worden toegeschreven'.

41 J. R. Bruijn, J. Lucassen, ed., Op de schepen der Oost-Indische Compagnie. Vijfartikelen van J. de Hullu (Groningen, 1980) 14.

42 Gebaseerd op Van der Woude, Noorderkwartier, 373-374. De zeelieden afkomstig van de Waddeneilanden zijn niet meegerekend.

43 Sexratio van Noordhollanders die tussen 1601 en 1700 in Amsterdam een eerste huwelijk wilden aangaan. 1601-1625: 98; 1626-1650: 97; 1651-1675: 86; 1676-1700: 85 .

Bron: S. Hart, 'Geschrift en getal', in: Idem, Geschrift en getal (Dordrecht, 1976) 145-146. 
deze zuigkracht aanmerkelijk minder sterk was dan werd aangenomen ${ }^{44}$. Vergelijken we deze sexratio met die van een aantal typisch zeevarende gemeenschappen als de Waddeneilanden, waar het merendeel van de mannelijke beroepsbevolking zijn brood in de zeevaart verdiende, dan blijkt de sexratio hier juist opvallend hoog te zijn (Terschelling 136, Texel 136, Vlieland 162). Het lijkt er zelfs op dat er een direct verband bestaat tussen de opkomst van de vrachtvaart in een bepaald gebied en een afnemend aantal bruidegoms uit dat gebied in de ondertrouwregisters van Amsterdam. In het geval van Ameland en Groningen, beide gebieden laatbloeiers als het gaat om de zeevaart, is deze 'Umwertung' duidelijk waarneembaar ${ }^{45}$.

Het belangrijkste dat we uit deze wankele cijfers kunnen concluderen, is dat de ondertrouwregisters, evenals de Sonttoltabellen, niet op zichzelfstaand kunnen worden gebruikt om er algemene conclusies met betrekking tot de scheepvaart aan te verbinden. In de tweede plaats lijkt de stroom van mannen uit de verschillende kustgebieden naar Amsterdam te stokken op het moment dat de eigen regionale vrachtvaart aan belang gaat toenemen.

In het afnemend aandeel Noordhollandse zeelui onder de bruidegoms zien Knotter en Van Zanden een bevestiging van de hypothese van Van der Woude dat het aantal zeelui in Noord-Holland afnam. Daartegenover staat dat het afnemend aantal buitenlandse zeelui die in Amsterdam in ondertrouw gingen (tussen 1680 en 1730), door Van der Woude wordt verklaard uit het toenemend belang van de eigen nationale scheepvaart $^{46}$. Uit hetzelfde materiaal kunnen we dus twee elkaar tegensprekende conclusies trekken. Een vermindering van het aantal zeevarende bruidegoms kan kennelijk zowel wijzen op een toename als een afname van het belang van de scheepvaart in een bepaald gebied. Gezien het feit dat juist in de zeventiende eeuw de scheepvaart in NoordHolland een hoge vlucht nam, lijkt de verklaring van Van der Woude mij plausibeler.

Het grootste bezwaar echter tegen het gebruik van de Amsterdamse ondertrouwregis-

44 S. Hart, 'Historisch-demografische notities betreffende huwelijken en migratie te Amsterdam in de 17e en 18e eeuw', Maandblad Amstelodamum, LV (1968) 69.

45

Sexratio Groningers en Amelanders, die tussen 1601 en 1800 in Amsterdam een eerste huwelijk wilden aangaan.

$\begin{array}{lrr} & \text { Groningen } & \text { Ameland } \\ 1601-1625 & 58 & 72 \\ 1626-1650 & 64 & 104 \\ 1651-1675 & 60 & 55 \\ 1676-1700 & 56 & 139 \\ 1701-1725 & 57 & 124 \\ 1726-1750 & 94 & 281 \\ 1751-1775 & 108 & 134 \\ 1776-1800 & 120 & 214\end{array}$

Bron: Collectie Hart, Gemeente Archief Amsterdam, PA 883.

46 Van der Woude, Noorderkwartier, 367. 
ters schuilt in het feit dat niet duidelijk is op welke tak van scheepvaart de betreffende bruidegoms dienst deden. Dat is van belang, want de verschillende takken van scheepvaart hadden een onderling sterk afwijkend recruteringspatroon. Uit een artikel van Hart over zeelieden te Amsterdam blijkt dat hij ook soldaten te water, konstabels en matrozen tot deze beroepsgroep heeft gerekend, wat erop duidt dat het om zeelui van allerlei slag ging ${ }^{47}$. Nog duidelijker blijkt het weinig representatieve karakter (als het gaat om de zeelui ter vrachtvaart) van de Amsterdamse ondertrouwregisters, wanneer we onderzoeken waarvandaan deze Noordhollandse zeelui kwamen. Voor een dergelijke vergelijking heb ik gebruik gemaakt van het door Hart verzamelde basismateriaal voor zijn artikel over zeelieden, die tussen 1651 en 1665 in Amsterdam in ondertrouw gingen ${ }^{48}$. Bekijken we de plaatsen van herkomst volgens de ondertrouwregisters en vergelijken we deze met de plaatsen van herkomst uit de periode 1700-1710, dan valt op dat juist de zeevarende gemeenschappen ontbreken in deze ondertrouwregisters ${ }^{49}$. Varenslieden uit de typisch zeevarende gemeenschappen in Noord-Holland benoorden het IJ gingen kennelijk niet in Amsterdam in ondertrouw.

Samenvattend kunnen we stellen dat het cijfermateriaal uit de ondeltrouwregisters van Amsterdam geen goede indruk geeft van ontwikkelingen in het aanbod van zeelieden uit Noord-Holland benoorden het IJ. Daarbij komt nog dat diverse aanwijzingen, waaruit duidelijk blijkt dat gedurende de gehele zeventiende eeuw met het aanbod van zeevarenden vanuit de kustprovincies en met de vrachtvaart als zodanig niets aan de hand was, volstrekt worden genegeerd.

In zijn uiterst gedetailleerde studie van de Sonttoltabellen en Sonttolregisters noemt Boon een groot aantal bootsgezellenbeurzen die niet alleen in de zeventiende, maar

47 S. Hart, 'Zeelieden te Amsterdam in de zeventiende eeuw. Een historisch-demografisch onderzoek', in: Idem, Geschrift en getal, 196.

48 Ibidem, 193-208.

49 De 'typisch' zeevarende dorpen ten zuiden van het IJ, zoals Aalsmeer, Amstelveen, Bloemendaal, Bussum, Diemen, Haarlem, Kudelstaart, Naarden, Nederhorst den Berg, Sloten, Sloterdijk, Spaarndam, Spaarnwoude, Uithoorn, Weesp en Zandvoort zijn niet meegerekend. Evenmin zijn in het overzicht betrokken Urk, Texel en de Halen (provincie Gelderland). Door deze uitsluiting vermindert het oorspronkelijke aantal van 272 'zeelieden' uit Noord-Holland met 96 tot een totaal van 176. De volgende zeevarende plaatsen komen niet voor in de ondertrouwregisters, maar wel in de scheepsverklaringen: Aartswoud, Abbekerk, Assendelft, Axwijk, de Bangert, Beets, Benningbroek, Berkhout, Binnenwijzend, Blokdijk, Blokker, Broek in Waterland, Broekoord, Callantsoog, Dirkshorn, Driehuizen, Durgerdam, Etershem, Oost- en West-Graftdijk, Grootschermer, Grosthuizen, Hauwert, Heiloo, Hern, Hobrede, Holysloot, Hoogkarspel, Hoogwoud, Ilpendam, Jisp, Katwoude, Langereis, Landsmeer, Lutjebroek, Marken, Middelie, Midwoud, Nibbixwoud, Noordeinde, Onderdijk, Oosthuizen, Oostwoud, Opmeer, Opperdoes, Oudendijk, Purmerland, Ransdorp, Rustenburg, Schardam, Scharwoude, Schellingwoude, Schellinkhout, Spanbroek, de Streek, Twisk, Wadwaaij, Warder, Watergang, Wervershoof, Westwoud, Wognum, Wijdenes, Zaandijk, Zuiderwoude, Zunderdorp, Zwaag en Zwaagdijk. De volgende plaatsen komen niet in de scheepsverklaringen voor maar wel in de ondertrouwregisters: Dorgeest, Haringhuizen, Oudenburg, Schagen, Schoorl, Velzen en Wogmeer. De volgende plaatsen komen voor zowel in de ondertrouwregisters als in de scheepsverklaringen: Akersloot, Alkmaar, Avenhorn, Barsingerhorn, Beemster, Beverwijk, Bovenkarspel, Broekerhaven, Buiksloot, Edam, Egmond, Enkhuizen, Graft, (de) Groe, Grotebroek, Den Helder, Hoogwoud, Hoorn, Huisduinen, Krommenie, Krommeniedijk, Lambert- 
ook aan het begin van de achttiende eeuw werden opgericht ${ }^{50}$. De oprichting van dergelijke fondsen wijst allerminst in de richting van een totale afwezigheid van de vrachtvaart als bron van werkgelegenheid. Uitgebreid onderzoek van G. J. A. Raven in de monsterrollen van de VOC heeft aangetoond dat vanaf 1682 tot en met 1720/1721 drie kwart van de bemanningen afkomstig was uit de Republiek ${ }^{51}$. De procentuele verdeling van Nederlanders en buitenlanders op de VOC-schepen was in de laatstgenoemde jaren $73,5 \%$ Nederlanders tegen $26,5 \%$ buitenlanders. Het merendeel van deze bemanningen kwam uit Holland, met name uit de steden $(90 \%)^{52}$. Vergelijken we dit percentage met dat van de geografische herkomst van het scheepsvolk op de vrachtvaart, dan blijkt dat deze haar volk vooral van het platteland recruteerde. Van de 1174 Westfriese zeelui, getraceerd in de notariële archieven in de periode 1700-1710, kwamen er $391(=33 \%)$ uit een van de drie steden, in het Noorderkwartier was slechts $7 \%$ (71 van de 1026) uit de steden afkomstig.

De vaak geciteerde opmerking uit een landbouwenquête uit 1800 wijst er eveneens op dat het met de achteruitgang van de vrachtvaart in Noord-Holland waarschijnlijk wel meeviel:

In de meeste dorpen in de districten van West-Friesland waren de boeren teffens zeeling. Hier was het kweekschool van matroozen, stuurlieden en schippers voor de koopvaardij, niet voor Oost-Indien of de oorlogschepen; dit wierd schande gerekend ${ }^{53}$.

Ook Lucassen is van mening dat de combinatie boer-zeeman in West-Friesland tegen het einde van de achttiende eeuw nog gewoon was, ook al beweert hij tegelijkertijd dat de vrachtvaart na 1680 als bron van werkgelegenheid in Noord-Holland vrijwel niets meer te betekenen had $^{54}$.

Een voorlopig laatste aanwijzing dat de vrachtvaart in Noord-Holland verre van verdwenen was, vinden we in de scheepsbouw. Deze behoorde in het eerste kwart van de achttiende eeuw nog tot de bloeiende sectoren van de nijverheid ${ }^{55}$. In 1707 lagen op een zestigtal werven in de Zaanstreek zo'n 306 schepen op stapel. Het lijkt me geen absurde gedachte een sterk verband tussen scheepsbouw en scheepvaart te veronderstellen.

schaag, Broek op Langendijk, Medemblik, Monnikendam, Nieuwendam, Nieuwe Niedorp, Oosterleek, Oostzaan, Petten, Purmerend, de Rijp, Schermer, Schermerhorn, Uitdam, Uitgeest, Ursem, Venhuizen, Westzaan, Wieringen, Wormer, Wijk aan Zee, Zaandam en Zijpe. Bron: Collectie Hart, Gemeentearchief Amsterdam, PA 883.

50 Boon, 'West Friesland and the Sound', 172-174. Voor bootsgezellenbeurzen in het Noorderkwartier, zie: Van Royen, Zeevarenden, 118, noot 8.

51 Resultaten in: Bruijn, Op de schepen der Oost-Indische Compagnie, 139.

52 J. R. Bruijn, 'De personeelsbehoefte van de VOC overzee en aan boord, bezien in Aziatisch en Nederlands perspectief', Bijdragen en mededelingen betreffende de geschiedenis der Nederlanden, XCI (1976) 237.

53 J. R. Bruijn, 'Zeevarenden', in: Maritieme Geschiedenis der Nederlanden, III, 162.

54 Lucassen, Naar de kusten van de Noordzee, 161.

55 S. C. van Kampen, De Rotterdamse particuliere scheepsbouw in de tijd van de Republiek (Assen, 1953) 84 . 
Is dan het verdwijnen van de zeelieden uit Noord-Holland volstrekt uit de lucht gegrepen? Daarop kunnen we alleen maar ontkennend antwoorden. De door Van der Woude veronderstelde ontwikkelingen echter hadden een ander verloop. Het proces van verdwijnen van Noordhollandse zeelui ging aanmerkelijk trager dan verwacht. Dat er op den duur de klad in de zeevaart kwam, daarover zijn we het denkelijk wel eens, maar dit proces heeft in elk geval pas na 1710 (wanneer precies is nog onduidelijk) zijn aanvang genomen en is waarschijnlijk geleidelijker gegaan dan we tot nu toe dachten. Afgezet tegen de door Van der Woude geschatte bevolkingsachteruitgang in Noord-Holland na 1680, in combinatie met de toenemende vraag naar zeelui van de kant van de VOC en de walvisvaart, nam de scheepvaart na 1700 - zij het tijdelijk als bron van werkgelegenheid in deze regio relatief nog toe ${ }^{56}$. In elk geval na 1710 ging het kennelijk mis. Het eerder genoemde onderzoek in de monsterrollen, opgemaakt door de Amsterdamse waterschout, uit het eerste kwart van de negentiende eeuw toont aan dat de Noordhollandse zeelui en schippers vrijwel geheel waren verdwenen. Interessant is overigens dat ook in deze jaren ongeveer een kwart (tussen de $24 \%$ en $28,6 \%$ ) van het varend volk op de Nederlandse vrachtvloot in Europese wateren uit het buitenland afkomstig was ${ }^{57}$.

Resteert ons na deze beschouwingen nog één vraag. Waardoor verdween op de lange duur de vrachtvaart als bron van werkgelegenheid in Noord-Holland? Op deze vraag heeft Van der Woude een interessante hypothese ontwikkeld in de Algemene Geschiedenis der Nederlanden, $\mathrm{V}^{58}$. Aan de hand van cijfermateriaal betreffende de bemanningen van de VOC-schepen, gepubliceerd door J. R. Bruijn ${ }^{59}$, kwam Van der Woude tot de conclusie dat de compagnie in de loop van de zeventiende en vooral in de achttiende eeuw een ware menseneter moet zijn geweest. Bedenken we dat in dezelfde periode de vrachtvaart bij voortduring bijna de helft van de totale werkgelegenheid op de scheepvaart voor haar rekening nam en dat de walvisvaart na 1700 een sterke groei doormaakte, dan kan men zich voorstellen dat de toch al grote druk van de VOC op het lokale arbeidspotentieel nog eens extra werd opgevoerd. Immers, de walvisvaart, maar ook de vrachtvaart waren allerminst risicoloze takken van bedrijvigheid. Al was de kans om op zee te overlijden in deze maritieme branches geringer dan in de dienst op de schepen van de VOC, dan moet het toch niet onwaarschijnlijk worden geacht dat de drie takken van scheepvaart te zamen de demografische groei van Holland geen

\footnotetext{
56 Zie bij voorbeeld: R. Willemsen, Enkhuizen tijdens de Republiek (Hilversum, 1988) 177. De bemanning van de VOC-schepen van de kamer Enkhuizen bestond in 1700/1701 voor $71 \%$ uit Noordhollanders, in $1710 / 1711$ voor $78 \%$. Het percentage buitenlanders daalde in dezelfde periode van $16 \%$ naar $11 \%$.

57 Het buitenlandse aandeel onder de zeelieden op de Europese vaart, zoals te berekenen uit een steekproef in hetzelfde materiaal (Bruijn, 'Zeevarenden', in: Maritieme Geschiedenis der Nederlanden, III, 157) te weten $34,5 \%$ buitenlanders, is te hoog.

58 A. M. van der Woude, 'Demografische ontwikkeling van de Noordelijke Nederlanden 1500-1800', in: Algemene Geschiedenis der Nederlanden (Bussum, 1980) V, 154-156.

59 Bruijn, 'Personeelsbehoefte', 218-248, speciaal 220, 223, 225, 233.
} 
goed hebben gedaan ${ }^{60}$. De VOC legde beslag op een deel van de stedelijke bevolking, de walvisvaart en de vrachtvaart namen het platteland voor hun rekening. Het is een hypothese, maar wellicht een die de moeite van het onderzoeken waard is.

Dit alles brengt ons tot de volgende conclusies. Van der Woude heeft ten onrechte nagelaten te vermelden dat het cijfermateriaal uit Zeevarenden door mij op een geheel andere wijze is uitgelegd dan hij doet. In de tweede plaats, de manier waarop Van der Woude mijn onderzoeksresultaten probeert 'in te passen' is niet overtuigend, de daarvoor aangevoerde argumenten zijn dat evenmin. De door Knotter (en Van Zanden) gebruikte gegevens uit de Amsterdamse ondertrouwregisters blijken niet of nauwelijks bruikbaar in het geval van de zeevarenden uit Holland benoorden het IJ, die hun brood verdienden op de vrachtvaart. De scheepvaart en de zeelui van Noord-Holland reageerden anders op bepaalde economische ontwikkelingen binnen en buiten de Republiek dan tot nu toe werd gemeend. Het proces van het verdwijnen van zeelieden zette op z'n vroegst pas na 1710 in en verliep waarschijnlijk trager dan tot op heden gesuggereerd. Of dit verdwijnen van de zeelieden uit Noord-Holland moet worden opgevat als een symptoom van een verslechtering, dan wel een verbetering van de economische positie van de Noordhollanders, blijft vooralsnog een interessante vraag.

60 Zie voor een nadere uitwerking van deze hypothese: Van Royen, 'Manning the Merchant Marine. The Dutch Labourmarket about 1700', te verschijnen in: Internationaljournal of Maritime History, I (1989). 
Woeringen 1288-1988: Brabantse overwinning, maar Keulse triomf *

\section{Recensieartikel door}

\section{R. VAN UYTVEN}

Sinds de laatste wereldoorlog heeft de politieke geschiedenis bij het grote publiek en bij historici veel aan interesse ingeboet, ofschoon de laatste decennia de zo gesmade 'histoire-batailles' aan een tegenoffensief schijnt te zijn begonnen, waarbij de militaire gebeurtenissen en de politieke feiten nu bij voorkeur in een bredere sociaal-economische en ideologische context worden geplaatst '. Het is inderdaad onmiskenbaar dat politiek en oorlogen en de veldslagen die er de kristallisatiepunten van zijn, op zeer diverse terreinen van de menselijke samenleving hun weerslag hebben. Poitiers 732, Hastings 1066, Bouvines 1214, Kortrijk 1302, Azincourt 1415, zij behoren alle tot de chronologische mijlpalen die bepaalde geschiedenishandboekjes, niet altijd ten onrechte, uitriepen tot 'dagen die geschiedenis maakten' ${ }^{2}$. In deze reeks hoort ook de slag van Woeringen (op de linker-Rijnoever $10 \mathrm{~km}$ ten noorden van Keulen) thuis. Alvorens gedetailleerd in te gaan op de twee uitgaven die ter herdenking van de slag van Woeringen in 1988 zijn verschenen, zal eerst een overzicht van de feitelijke gebeurtenissen worden gegeven en wordt vervolgens de voorstelling van deze slag in de historiografie belicht.

\section{Het verloop der gebeurtenissen}

Op 5 juni 1288 werd te Woeringen beslist over de sinds 1283 anslepende Limburgse successieoorlog ${ }^{3}$. Voor de tijdgenoten was de slag ogenschijnlijk niet veel meer dan een soort godsoordeel tussen de mededingers naar het bezit van het hertogdom Limburg, een niet eens zo uitgestrekt en bovendien versnipperd gebied ten oosten van de Maas, met slechts enkele burchten en kleinere steden, waarvan Limburg op de Vesdre (Vesder of Weser) een van de belangrijkste was. Het probleem over de erfenis was gerezen in 1280 bij de dood van hertog Waleram IV van Limburg zonder direkte mannelijke erfgenaam. In 1282 bevestigde de weinig machtige Rooms-koning Rudolf van Habsburg Walerams erfdochter Irmgarde en haar gemaal Reinald, graaf van Gelre, in het bezit van het hertogdom, dat Reinald ook na de dood van zijn kinderloze vrouw levenslang in vruchtgebruik zou mogen houden. Bij het overlijden van Irmgarde (juni 1283) eiste niettemin Adolf, graaf van Berg en kleinzoon in mannelijke lijn van hertog Hendrik van Limburg, de grootvader van Irmgarde, Limburg op. Al vlug beseffend dat hij zijn aanspraken niet zou kunnen waarmaken, droeg Adolf van Berg zijn erfrecht op Limburg over aan Jan I, hertog van Brabant, die onmiddellijk het hertogdom binnenviel. Meteen kreeg

* Naar aanleiding van twee herdenkingsuitgaven: Wemer Schäfke, ed., Der Name der Freiheit 12881988. Aspekte Kölner Geschichte von Woningen bis Heute ( 2 dln.; Keulen: Kölnisches Stadtsmuseum, 1988, 677+151 blz.) en Wilhelm Janssen, Hugo Stehkämper, ed., Der Tag bei Worringen: 5. Juni 1288 (Veröffentlichungen der Staatlichen Archive des Landes Nordrhein-Westfalen, Reihe C, Quellen und Forschungen, Band XXVII; Düsseldorf: Selbstverlag des Nordrhein-Westfälischen Hauptstaatsarchivs, 1988, x + 478 blz.), ook versehenen in Mitteilungen aus dem Stadtarchiv von Köln, LXXII. Heft en Blätter für deutsche Landesgeschichte, CXXIV (1988) 1 -453. In het vervolg worden zij geciteerd als Name en Tag.

1 B. Guenée, L' Occident aux XTVe et XVe siècles: Les Etats (Parijs, 1971); Ph. Contamine, La guerre au Moyen Age (Parijs, 1980; 2e dr.1986); J. R. Hale, War and Society in Renaissance Europe, 1450-1620 (Leicester, 1985).

2 Vgl. Y. Renouard, '1212-1216. Comment les traits durables de l'Europe occidentale moderne se sont définis au début du XIIle siècle', Annales de l'Université de Paris, XXVIII (1958) 5-21 ; De reeks 'Trente journées qui ont fait la France' (Gallimard, Parijs, 1964 vlg.).

3 Hetgeen volgt, steunt, tenzij anders aangegeven, op de twee herdenkingsuitgaven. 